\title{
Pengaruh Brand Experience terhadap Kepuasan Pelanggan serta Dampaknya pada Repurchase Intention (Survei pada Pelanggan Klinik Skin Care di Kota Bandung)
}

\author{
Ashri Hasian Ekaputr ${ }^{1}$, Agus Rahayu², Lili Adi Wibowo ${ }^{3}$ \\ Mahasiswa Magister Manajemen Bisnis \\ Sekolah Pasca Sarjana Universitas Pendidikan Indonesia
}

\begin{abstract}
Abstrak
Pertumbuhan pada industri kecantikan membuat persaingan bisnis menjadi dinamis dan kompetitif. Klinik Skin Care yang ada saat ini perlu berupaya meningkatkan repurchase intention pelanggan. Repurchase intention pelanggan merupakan hal yang sangat penting bagi kelangsungan usaha pada setiap perusahaan. Aspek yang dapat menciptakan repurchase intention adalah kepuasan pelanggan, strategi yang tepat untuk mencapai kepuasan pelanggan yaitu menciptakan pengalaman merek bagi pelanggan. Penelitian ini bertujuan untuk mengetahui pengaruh brand experience terhadap kepuasan pelanggan serta dampaknya pada repurchase intention pada pelanggan klinik Skin Care di Kota Bandung. Jenis penelitian yang digunakan adalah deskriptif verifikatif, dan metode yang digunakan adalah explanatory survey dengan teknik simple random sampling, dengan jumlah sampel 375 responden. Teknik analisis data yang digunakan adalah path analysis dengan alat bantu software komputer SPSS 23.0. Hasil penelitian secara keseluruhan nilai perhitungan yang diperoleh melalui analisis jalur lebih besar dibandingkan dengan yang terdapat pada tabel. Artinya secara keseluruhan terdapat pengaruh yang signifikan dari brand experience terhadap kepuasan pelanggan serta dampak pada repurchase intention.
\end{abstract}

Kata Kunci : Brand Experience, Kepuasan Pelanggan, Repurchase Intention

\section{PENDAHULUAN}

Saat ini banyak perusahaan yang bergerak di bidang kecantikan yang menyebabkan persaingan bisnis semakin kompetitif. Dengan potensi yang baik pada industri kecantikan, maka perusahaanperusahaan pun membuat berbagai jenis perawatan kecantikan, seperti yang sekarang ini sudah banyak di pasaran yaitu spa dan perawatan kulit. Dari kedua perawatan kecantikan tersebut salah satu yang sekarang ini sedang marak diperbincangkan adalah perawatan kulit. Hal ini dapat dilihat pada gambar berikut:

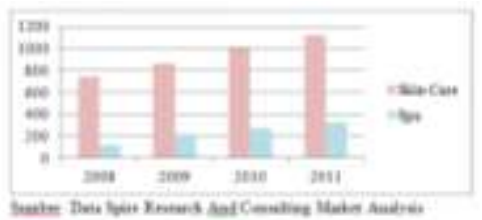

Sumber: Data Spire Research And Consulting Market Analysis

GAMBAR 1.1 DATA MARKET ANYLISIS

terlihat dengan jelas bahwa pertumbuhan pasar skin care selalu mengalami peningkatan, dengan rata- rata pertumbuhan sebesar 7\% setiap tahunnya dibandingkan dengan spa. Pertumbuhan pasar skin care yang terjadi sekarang ini sejalan dengan kondisi usaha di industri kecantikan dengan maraknya perusahaan-perusahaan yang bergerak di industri kecantikan.

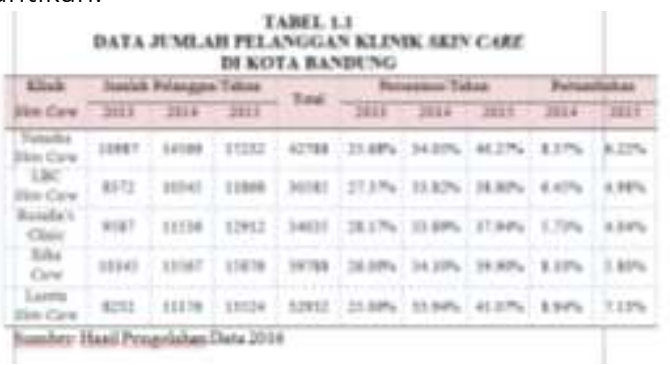

ditunjukan bahwa ternyata dari tahun 2013 sampai 2015 Klinik Skin Care mengalami kenaikan Jumlah pelanggan, namun mengalami penurunan pertumbuhan dari setiap tahunnya. Pertumbuhan yang terjadi pada Natasha Skin Care dari tahun 2013 ke 2014 yaitu 8,37\% sedangkan pertumbuhan dari tahun 2014 ke tahun 2015 sebesar 6,22\%, dapat dilihat bahwa penurunan terjadi dari pertumbuhan tahun 2014 dan tahun 2015 mengalami penurunan 2,15\%. 
Hal seperti ini juga dialami oleh perusahaan skin care lainnya yang menjadi objek penelitian. Penurunan pertumbuhan ini dipengaruhi oleh semakin banyaknya kompetitor yang ikut meramaikan pasar skin care, terbukti dari tahun 1982 sampai sekarang 2016 banyak sekali perusahaan yang bermunculan. Setiap tahunnya usaha perusahaan skin care ini semakin berkembang dan semakin banyak menarik konsumen. Atas dasar latar belakang yang dikemukakan, maka penelitian yang dilakukan untuk menganalisis faktor-faktor yang mempengaruhi intensitas minat beli kembali pelanggan dengan judul: "Pengaruh Brand Experience terhadap Kepuasan Pelanggan dan Dampaknya pada Repurchase Intention pada Klinik Skin Care di Kota Bandung".

\section{KERANGKA PENELITIAN \& HIPOTESIS}

Menurut Brakus, Schmitt dan Zarantonello (2009) brand experience didefenisikan sebagai sensasi, perasaan,kognisi dan tanggapan konsumen yang ditimbulkan oleh merek, terkait rangsangan yang ditimbulkan oleh desain merek, identitas merek, komunikasi pemasaran, orang dan lingkungan merek tersebut dipasarkan. Untuk dapat mendefenisikan lebih jauh mengenai brand experience Brakus, Schmitt dan Zarantonello (2009).

Menurut Anderson et al., Edvardsson dalam Fandy Tjiptono (2011:432) kepuasan pelanggan berkontribusi pada sejumlah aspek krusial, seperti terciptanya loyalitas pelanggan, meningkatnya reputasi perusahaan, berkurangnya elastisitas harga, berkurangnya biaya transaksi masa depan dan meningkatnya efesiensi dan produktivitas karyawan.

Minat beli menunjukan reaksi emotional yang dihasilkan dari evaluasi keseluruhan konsumen terhadap suatu produk, dan juga menunjukan kemungkinan bahwa konsumen ingin membeli produk (Grewal, et.al dalam Wu Chen, 2014). Niat beli adalah predictor yang paling tepat dari perilaku pembelian (Morwitz dan Schittlein dalam Wu dan Chen, 2014). Pengertian minat beli menurut Cronin dalam Meysam (2012:2)

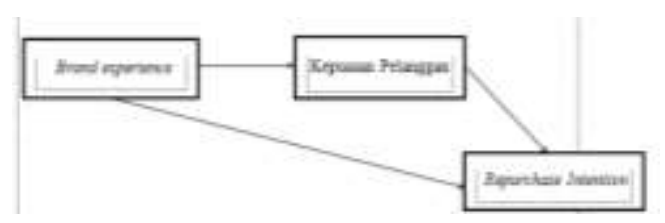

Terdapat pengaruh brand experience terhadap kepuasan pelanggan serta dampaknya pada repurchase intention

Terdapat pengaruh brand experience terhadap kepuasan pelanggan

Terdapat pengaruh brand experience terhadap repurchase intenton

Terdapat pengaruh kepuasan pelanggan terhadap repurchase intention

\section{METODE PENELITIAN}

Penelitian ini menggunakan pendekatan manajemen pemasaran yang berfokus kepada pengaruh brand experience terhadap kepuasan pelanggan dan dampaknya pada repurchase intention pada Klinik Skin Care di Bandung. Adapun yang menjadi objek penelitian sebagai Variabel $(X)$ brand experience meliputi sensory, affective, intellectual, dan behavioral, variabel $(Y)$ kepuasan pelanggan, variabel (Z) dan repurchase intention meliputi repeat purchase intention, repurchase probability dan word of mouth.

Teknik analisis data yang dipergunakan untuk mengetahui hubungan korelatif dalam penelitian ini yaitu teknik analisis jalur (path analysis).

Hasil perhitungan rumus slovin didapatkan bahwa sampel yang digunakan berjumlah 375,05 responden, dibulatkan menjadi 375 responden

\section{HASIL DAN PEMBAHASAN}

pengaruh brand experience terhadap kepuasan pelanggan serta dampaknya terdahadap keputusan membeli ulang. Hipotesis penelitian ini adalah brand experience $(X)$, Kepuasan pelanggan $(Y)$ berpengaruh terhadap repurchase intention (Z). Hipotesis ini diuji 
secara simultan maupun parsial dengan menggunakan SPSS 23.0 for windows.

TABEL 4.1

PENGUJIAN SECARA SIMULTAN

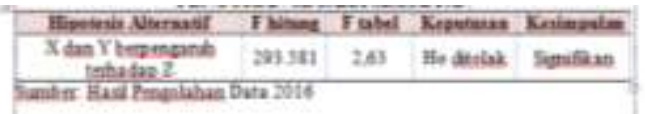

Tabel di atas menunjukan pengujian untuk uji $\mathrm{F}$ yang diambil dari Anova dengan tingkat probabilitas (Sig) $=0,000$, karena Sig $\leqslant 0,05$ maka keputusannya adalah HO ditolak. Artinya secara simultan (keseluruhan) terdapat pengaruh yang positif antara pengaruh brand experience terhadap kepuasan pelanggan serta dampaknya terdahadap repurchase intention pada pelanggan Klinik Skin Care di Kota Bandung.

TABEL 4.2

HASIL PENGUJIAN KOEFISIEN JALUR PENGARUH LANGSUNG DAN TIDAK LANGSUNG

\begin{tabular}{|c|c|c|c|}
\hline \multirow{2}{*}{ 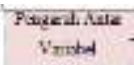 } & \multicolumn{3}{|c|}{ Paiscal } \\
\hline & Inyrute & Twolsome & Tत्ता \\
\hline $\mathrm{x} \rightarrow \mathrm{Y}$ & ก אמב3 & & 6503 \\
\hline$x=z$ & -0045 & JASE & क.1 \\
\hline$Y=Z$ & -0035 & - & 0.3 .6 \\
\hline
\end{tabular}

Dapat aıketanuı banwa totaı koetısıen jaıur antara brand experience dan kepuasan pelanggan sebesar 0,78 dengan $\mathrm{R}$ square 0,612 . Sehingga dapat diketahui nilai dari koefisien residu melalui rumus berikut:

$$
\begin{aligned}
& \mathrm{P}_{\gamma_{\varepsilon}}=\sqrt{1-} R_{y(x)}^{2} \\
& \mathrm{P}_{\gamma_{\varepsilon}}=\sqrt{1-0,612} \\
& \mathrm{P}_{Y_{\varepsilon}}=\sqrt{0,388} \\
& \mathrm{P}_{\gamma_{\varepsilon}}=0,622
\end{aligned}
$$

Hasil tersebut menunjukan bahwa brand experience secara simultan mempengaruhi customer satisfaction yaitu sebesar $78 \%$. Sedangkan pengaruh dari luar yang tidak diteliti $(0,622)^{2}=0,39 \times 100 \%=39$ $\%$.

\section{KESIMPULAN}

Gambaran brand experience, kepuasan pelanggan dan repurchase intention pada Klinik Skin Care di Kota Bandung telah dinilai baik oleh pelanggan. Dapat dilihat dari brand experience, kepuasan pelanggan dan repurchase intention memperoleh penilaian pelanggan dengan tinggi.
Hal ini terbukti bahwa penerapan strategi brand experience telah berjalan baik di Klinik Skin Care di Kota Bandung, sehingga terciptanya kepuasan pelanggan yang positif dan terciptanya minat membeli ulang pelanggan terhadap suatu produk yang sama dalam satu perusahaan.

Pengaruh brand experience terhadap kepuasan pelanggan memiliki pengaruh positif dampaknya pada keputusan pembelian ulang dengan pengaruh yang cukup tinggi. Temuan tersebut menunjukan bahwa semakin tinggi penerapan brand experience yang menghubungkan antara Klinik Skin Care di Kota Bandung dengan pelanggan, akan semakin tinggi kepuasan pelanggan terhadap Klinik Skin Care tersebut, maka semakin tinggi pula minat pembelian ulang produk atau jasa pada Klinik Skin Care di Kota Bandung.

Pengaruh brand experience terhadap kepuasan pelanggan yang dirasakan oleh pelanggan Skin Care di Kota Bandung termasuk pada kategori yang cukup tinggi. Temuan penelitian tersebut menunjukkan bahwa penerapan brand experience telah dilaksanakan dengan baik oleh perusahaan untuk mengkatkan kepuasan pelanggan. Dimensi dari brand experience yang paling tinggi yaitu sensory. Dimensi tersebut mendapat perolehan tertinggi dikarenakan ketika sebuah merek dapat membuat kesan kuat dengan menarik pada kelima panca indera. Merek dapat dirasakan dan dinikmati dengan kelima panca indera langsung saat kita sejak pertama merasakan merek tersebut.

\section{REKOMENDASI}

Tanggapan pengguna terhadap indikator-indikator repurchase intention dinilai baik, adapun masih terdapat indikator yang harus diperbaiki yaitu pada dimensi repurchase probability dengan presentase sebesar 22,63\%. Kecenderungan pelanggan untuk menggunakan produk dari merek yang sama 
Kota Bandung)

merupakan hal penting yang menjadi asset perusahaan karena akan membantu meningkatkan pendapatan penjualan. Perusahaan dalam menjalankan aktivitasnya mempunyai tujuan memperoleh keuntungan. Selain itu perusahaan juga ingin memberikan kepuasan kepada pelanggannya atas produk yang yang dihasilkannya, sehingga pelanggan akan loyal terhadap merek atau bahkan pelanggan akan melakukan pembelian ulang dari produk tersebut. Saran dari peneliti yaitu perusahaan harus dapat membaca pasar dengan baik, keinginan dari konsumen yang bermacam-macam dengan menyesuaikan dengan kebutuhan konsumen, dan persaingan antar pasar yang semakin bersaing.

Kelemahan pada penelitian ini diantaranya adalah penelitian yang dilakukan pada satu waktu (cross sectional) sehingga ada kemungkinan perilaku individu yang cepat berubah dari waktu ke waktu, selain itu variabel yang digunakan dalam penelitian ini belum mewakili semua faktor-faktor yang mempengaruhi keputusan pembelian ulang. Untuk penelitian selanjutnya disarankan untuk memperbarui kembali teori mengenai brand experience maupun melakukan penelitian pada objek yang lebih spesifik.

\section{DAFTAR PUSTAKA}

Ali Kazemi et al., (2013). "Analyzing the Effect of Customer Equity on Repurchase Intentions". International Journal of Academic Research in Business and Social Sciences, Vol. 3, No. 6 ISSN: 2222-6990.

Azize Sahin (2012), "The effects of Brand Experience and service quality on Repurchase Intention: The role of brand relationship quality". African Journal of Business Management Vol.6 (45), pp. 1119011201.

Christina Sagala, et al., (2015). "Influence of Promotional Mix and Price on Customer Buying Decision toward Fast Food sector". International Journal of Scientific and Research Publications, Volume 4, Issue 1, ISSN 2250-3153
Fandy Tjiptono Ph. D,. 2011. Pemasaran Jasa. Jatim: Bayumedia Publisihing. Anggota IKAPI Jatim.

Fandy Tjiptono Ph. D,. and Gregorius Chandra 2012. Pemasaran Strategik. Edisi 2. Yogyakarta: Andi.

Hussain Shah, et al., (2012). "The Impact of Brands on Consumer Purchase Intentions". Asian Journal of Business Management 4(2): 105-110, ISSN: 20418752

Kotler, Philip and Kevin Lane Keller. 2016. Marketing Management $15^{\text {th }}$ Edition. New Jersey: Pearson Prentice Hall.

Kotler, Philip, dan Gary Armstrong. 2014. Principles of Marketing $14^{\text {th }}$ Edition. New Jersey: Pearson Educations, Inc.

Richard Chinomona, (2013). "The Influence Of Brand Experience On Brand Customer Satisfaction, Trust And Attachment In South Africa". International Business \& Economics Research Journal -Volume 12, Number 10 .

Riduwan dan Engkos. 2012.Cara Mudah Menggunakan dan Memaknai Path Analysis. Bandung: Alfabeta.

Run Huang, at al,. 2015. "The impact of Brand Experienceson brand resonance in multi-channel fashion retailing". Journal of Research in Interactive Marketing, Vol. 9 No. 2, pp. 129-147.

Schiffman \& Kanuk. (2004). Perilaku Konsumen (edisi 7). Jakarta : Prentice Hall

Schmitt, Bernd, (1999), "Experiential Marketing", Journal of Marketing Management, Vol.15, p.53-67.

Sigit Haryono (2015), "The Effects of Service Quality on Customer Customer Satisfaction, Customer Delight, Trust, Repurchase Intention, and Word of Mouth", European Journal of Business and Management Vol.7, No.12.

Thomson, M., Maclnnis, D.J. and Park, C.W. (2010), "The ties that bind: measuring the strength of consumers' emotional attachments to brands", Journal of Consumer Psychology, Vol. 15 No. 1, pp. 77-91.

Ugur Baser et al., (2015). Examining The Effect Of Brand Experience On Consumer Satisfaction, Brand Trust And Brand Loyalty. Marmara 
Üniversitesi i.I.B. Dergisi YIL 2015, CILT XXXVII, SAYI II, S. 101-128 Doi No: 10.14780/iibd.51125. 